\title{
AN UNUSUAL ILLNESS IN YOUNG CHILDREN ASSOCIATED WITH AN ENTERIC VIRUS
}

\author{
BY \\ MARY CRAWFORD, A. D. MACRAE and J. N. O'REILLY \\ From the Queen Elizabeth Hospital for Children, Shadwell, \\ and the Virus Reference Laboratory, Public Health Laboratory Service, Colindale, London
}

(RECEIVED FOR PUBLICATION MARCH 7, 1956)

During August and September, 1954, 10 babies (seven girls and three boys with ages ranging from 3 to 14 months) were admitted to the Shadwell branch of the Queen Elizabeth Hospital for Children. They all showed a similar clinical picture, of uncertain aetiology, with irritability, fever, a maculopapular rash, enlargement of superficial lymph nodes, vomiting and diarrhoea. Changes in the cerebrospinal fluid (C.S.F.) were found. None was seriously ill at any time and all made a straightforward recovery.

Eight patients came from neighbouring East End (E.1 and E.14) districts of London. One patient came from South Ockendon, Essex, a housing estate to which many Shadwell families have moved, and one patient developed the illness while in hospital with a chest complaint.

Case Summaries
Case 1. R.C., aged 14 months, a girl, had had meningococcal septicaemia in March, 1954. She lived in E.1.

Four days before admission (August 11, 1954) she developed diarrhoea with watery brown stools; no blood or mucus. On the day of admission, she was very irritable, vomited all food and fluids, the bowels were opened four times, and she developed a rash.

On admission on August 15 her temperature was $102 \cdot 4^{\circ} \mathrm{F}$., pulse 136 , and respiration 36 . She was still very irritable, and had a fine, reddish-brown, discrete maculo-papular rash on the trunk, thighs and face, which faded on pressure, but no petechiae. The fauces were red, but without exudate. The cervical lymph nodes in the anterior and posterior triangles were enlarged.

No abnormality was detected in the cardiovascular and respiratory systems and in the abdomen. No meningism was found.

On August 15, the C.S.F. contained 12 cells (all lymphocytes), protein, $35 \mathrm{mg}$. per $100 \mathrm{ml}$., sugar, normal reduction, and a culture produced no growth.

On August 16 white blood cells numbered 12,800 (lymphocytes $68^{\circ}$ ), and on August 19, 8,200 (lymphocytes $80^{\circ}$ \%).
No pathogens were isolated from the stools. A throat swab showed pneumococci and $N$. catarrhalis, and a nose swab pneumococci.

Glucose fluids were given for 24 hours.

The temperature ranged from 99 to $100^{\circ}$ over the first five days and subsequently became normal. No vomiting after admission. Stools became well formed in three days. The rash gradually faded, first from the limbs, then from the face and trunk, and disappeared three days after admission. The child was discharged home, well, on August 23.

Case 2. M.R., aged 4 months, a girl, two days before admission screamed whenever touched. Her home was in E.1. She was very irritable, but took feeds and did not vomit. The stools were green. She developed a rash on the day of admission (August 22). On admission the temperature was $102 \cdot 4^{\circ} \mathrm{F}$., pulse 160 , and respiration 36. She was very irritable, and had a fine, reddishbrown, discrete maculo-papular rash on the trunk, limbs and face; this faded on pressure. There were no petechiae.

The fauces and tonsils were red, without any exudate. The right tonsillar and left occipital lymph nodes were enlarged.

She had tachycardia.

Nothing abnormal was found in the respiratory system and abdomen, and no meningism.

The C.S.F. on August 22 contained 100 cells (polymorphs 26, lymphocytes 74), protein, $15 \mathrm{mg}$. per $100 \mathrm{ml}$., sugar, normal reduction, and no growth on culture. On August 30 there were four cells (polymorphs 2, lymphocytes 2). A white blood count on August 22 gave 24,000 (lymphocytes $64^{\circ}$ ) and on August 24, 13,400 (lymphocytes $70^{\circ}$, ).

A throat swab showed Subtilis and scanty pneumococci, and a nose swab diphtheroids.

The temperature became normal within 24 hours of admission and the rash faded in three days. The baby's general condition was good and she fed well throughout. She was discharged home, well, on August 31.

Case 3. L.H., aged 6 months, living in E.1, a girl, had cerebral palsy, chickenpox encephalitis when 4 months old, and otitis media. She was subject to 
convulsions and was on phenobarbitone, grain $\frac{1}{4}$ t.d.s. She always lies with the head retracted.

She had been crying, irritable, restless and generally twitching for 24 hours. She had refused three feeds, but was not vomiting. The bowels were open three times with normal stools. The rash developed on the day of admission (August 23, 1954). On admission the temperature was $102 \cdot 4^{\circ} \mathrm{F}$., pulse 144 , respiration 36 . She was very irritable, with generalized myotonic spasms. She had a fine, reddish-brown, discrete, maculo-papular rash on the face, trunk, limbs and feet, fading on pressure, but no petechiae.

The fauces and tonsils were red without exudate.

The occipital and left cervical lymph nodes were enlarged. Nothing abnormal was noted in the cardiovascular and respiratory systems or in the abdomen.

She had generalized hypertonia, and head retraction unchanged from her previous stay in hospital with chickenpox encephalitis. Tension was normal in the anterior fontanele.

The C.S.F. on August 23 contained 376 cells (polymorphs $78 \%$, lymphocytes $22 \%$ ), protein $15 \mathrm{mg}$. per $100 \mathrm{ml}$., sugar, normal reduction, and no growth on culture. On August 30, cells numbered 12 (polymorphs 4, lymphocytes 8).

A white blood count on August 23 gave 16,000 (polymorphs $48 \%$, lymphocytes $37 \%$, monocytes $15 \%$ ).

A throat swab grew diphtheroids and $N$. catarrhalis, and a nose swab Staph. aureus. No pathogens were isolated from a rectal swab. The temperature became normal 24 hours after admission. The rash faded in three days and the convulsive movements subsided over five days. There was no vomiting or diarrhoea and the baby took feeds well and gained weight. Treatment with phenobarbitone was continued during the illness and after recovery.

Case 4. J.D., aged 7 months, a girl, living in Dagenham, Essex, was admitted on August 13, 1954, with a chest infection.

On admission her temperature was $99^{\circ} \mathrm{F}$., and she was a pale baby. The fauces and tonsils were red. She had a paroxysmal cough, and thonchi were heard at the bases of both lungs.

A chest radiograph showed nothing abnormal.

A white blood count gave 40,000 (polymorphs $16 \%$, lymphocytes $84 \%$ ).

A throat swab showed pneumococci and a nose swab N. catarrhalis.

The baby was treated with chloramphenicol as a case of pertussis for five days.

On August 24 her temperature was $102^{\circ} \mathrm{F}$. (previously normal for one week), and she was very irritable, but had no diarnhoea or vomiting. On examination she had a faint, reddish-brown, discrete, maculo-papular rash on the trunk and arms, fading on pressure. She had no petechiae and no enlarged lymph nodes.

The C.S.F. on August 24 contained 84 cells (polymorphs 28, lymphocytes 56), protein $15 \mathrm{mg}$. per $100 \mathrm{ml}$., sugar, normal reduction, and no growth on culture.
A white blood count gave 20,000 (polymorphs $37 \%$, lymphocytes $56 \%$, monocytes $7 \%$ ).

No pathogens were isolated from the stools.

The temperature became normal in 36 hours. There was no vomiting or diarrhoea. The rash faded in five days. The baby lost $3 \mathrm{oz}$. in weight while febrile, but gained $9 \mathrm{oz}$. subsequently before discharge. She was discharged home, well, on September 1.

Case 5. S.U., aged 9 months, a gir, living in E.1, was admitted on September 5, 1954. On admission she was feverish, very irritable and had been off her feeds for 24 hours before admission; she was not vomiting. The bowels were open normally (temperature $104^{\circ} \mathrm{F}$, pulse 140, respiration 36). A fine macular rash, reddishbrown, on the trunk only, fading on pressure, had developed a few hours before admission, but with no petechiae. Nothing abnormal was seen in the throat. The cervical and occipital lvmph nodes were enlarged.

The cardiovascular and respiratory systems were normal, as was the abdomen. There was no meningism.

The C.S.F. on September 4 contained 154 cells (mainly polymorphs), protein $30 \mathrm{mg}$. per $100 \mathrm{ml}$., sugar, normal reduction, and no growth on culture.

On September 17, the C.S.F. contained 18 cells (polymorphs 16, lymphocytes 2).

A white blood count on September 4 gave 37,000 (polymorphs $64 \%$, lymphocytes $30 \%$ ), and on September 7, 16,000 (polymorphs $29 \%$, lymphocytes $62 \%$ ). A blood culture showed no growth. A throat swab showed Strep. viridans and $N$. catarrhalis, and a nose swab Staph. aureus.

The temperature became normal in 24 hours. The child was very reluctant to take feeds for the first $\mathbf{4 8}$ hours, but had no vomiting or diarrhoea. The rash faded during the five days after admission, and she had recovered clinically by September 11 . She was kept in hospital for social reasons until discharged home on September 22.

This case was treated with systemic penicillin and oral sulphonamides for the first three days in view of the possibility of a meningococcal infection.

Case 6. V.B., aged 12 months, a girl whose home was in E.14, was admitted on September 10, 1954.

She vomited four times on the day before admission and developed a rash on the trunk. On the day of admission, she vomited three times. The rash spread to limbs and face. She was feverish for 24 hours, and took clear fluids only. She had no diarrhoea. On admission her temperature was $99.4^{\circ} \mathrm{F}$., pulse 136 , and respiration 36 . She was not an ill child, and was crying heartily.

A fine, reddish-brown, discrete, maculo-papular rash was seen on the trunk, limbs, face and soles of the feet, fading on pressure. She had petechiae on the face and chin. The fauces and tonsils were red, but without exudate. The cervical, occipital, axillary and inguinal lymph nodes were all enlarged.

Nothing abnormal was noted in the cardiovascular and respiratory systems or in the abdomen. She had no meningism. 
The C.S.F. on September 10 contained 40 cells (lymphocytes $100^{\circ}$ ), protein $10 \mathrm{mg}$. per $100 \mathrm{ml}$., sugar, normal reduction, and no growth on culture. A second examination on September 20 showed 8 cells (polymorphs 4, lymphocytes 4).

A white blood count on September 10 gave a total of 20,400 (polymorphs $53^{\circ} \mathrm{o}$, lymphocytes $42^{\circ} \mathrm{o}$ ).

Platelets numbered 350,000 per c.mm. A throat swab showed pneumococci as also did a nose swab.

Her temperature varied from $98^{=}$to $99 \cdot 8^{*}$ F. for the first six days after admission. She did not vomit. The maculo-papular rash faded gradually during the 10 days after admission and the petechiae disappeared in four more days.

She was discharged home, well, on September 28.

Case 7. P.W., aged 4 months, a boy from E.1, three days before admission was very irritable and flushed. A rash appeared on the face and then spread to the trunk and limbs. He vomited twice two days before admission and once on the day before. He refused feeds for 24 hours. The bowels were normal. On admission on September 12 the temperature was $98 \cdot 9^{\circ} \mathrm{F}$., pulse 124 , respiration 24. He had a discrete, reddish-brown, maculo-papular rash on the face, trunk and limbs, fading on pressure, but no petechiae. The fauces and tonsils were red, but without exudate. He had no enlarged lymph nodes. Nothing abnormal was found in the cardiovascular and respiratory systems or in the abdomen, nor any meningism.

The C.S.F. on September 12 contained 76 cells (polymorphs 19 , lymphocytes 57 ), protein $25 \mathrm{mg}$. per $100 \mathrm{ml}$., sugar, normal reduction, and no growth on culture. A second specimen on September 22 showed 4 cells (polymorphs 2, lymphocytes 2). A white blood count gave 17,300 (lymphocytes $78^{\circ} .0$ ).

A throat swab grew scanty pneumococci and $N$. catarrhalis and a nose swab $\boldsymbol{N}$. catarrhalis. No pathogens were isolated from a rectal swab. The baby continued afebrile after admission. He vomited twice and passed two loose stools in the first 48 hours. The rash faded in five days. There was no enlargement of the lymph nodes in this case at any time. He was discharged home, well, on September 25.

Case 8. M.J., aged 5 months, a boy from E.1, vomited three times and was flushed and irritable on the day before admission; on that day, stools were loose and a generalized 1ash appeared. He was admitted on Septembər 14,1954 , when his temperature was $100^{\circ} \mathrm{F}$., pulse 140 , respiration 32 . He was very irritable, and had a generalizad, discrete, reddish-brown maculo-papular rash on the trunk, limbs, hands and feet, but few lesions on the face. The rash faded on pressure, and he had no petechiae. The tonsils and fauces were red, but without exudate. He had no enlarged lymph nodes. Nothing abnormal was found in the cardiovascular, respiratory or central nervous systems, nor in the abdomen.

A sample of C.S.F. taken on September 14 yielded cells nil, protein $10 \mathrm{mg}$. per $100 \mathrm{ml}$., sugar, normal reduction, and no growth on culture. Examination of the C.S.F. on September 15 gave 10 cells (polymorphs 2, lymphocytes 8) and on September 23, 2 cells (lymphocytes). A white blood count on September 14 gave 8,200 (polymorphs $30^{\circ}$, lymphocytes $66^{\circ}$ ).

A throat swab showed a scanty growth of haemolytic streptococci and pneumococci, a nose swab Staph. aureus, and a stool Proteus vulgaris.

The temperature became normal within 12 hours, and there was no further vomiting or diarrhoea. On September 21 small cervical lymph nodes on both sides were palpable. Petechiae appeared on the right cheek. The rash faded five days after admission.

The baby was discharged home, well, on September 25.

Case 9. T.B., aged 6 months, a boy, was admitted in September 20 from his home in E.14. For three days before admission he had been very irritable, feverish and difficult to feed, and two days before had spots on the stomach. One day before he had a rash on the face, limbs and trunk, but no vomiting and the bowels were normal. On admission his temperature was $100 \cdot 2=\mathrm{F}$., pulse 132, respiration 30. He was very irritable, and had a fine, reddish-brown maculo-papular rash on the face, trunk, limbs and soles of the feet, fading on pressure.

The fauces were red, but without exudate. The cervical, occipital, axillary and inguinal lymph nodes were all enlarged. The cardiovascular, respiratory and central nervous systems appeared normal as did the abdomen.

A sample of C.S.F. on September 20 yielded 46 cells (polymorphs 4, lymphocytes 42), protein $20 \mathrm{mg}$. per $100 \mathrm{ml}$., sugar, normal reduction, and no growth on culture. On September 30 cells numbered 84 (polymorphs 10, lymphocytes 74), and on October 11 cells 14 (polymorphs 3, lymphocytes 11).

A white blood count on September 20 gave 17,000 (lymphocytes $70^{\circ}$ ).

Platelets numbered 310,000, and bleeding and clotting times were normal. The Paul Bunnell test was negative.

A throat swab grew $N$. catarrhalis and diphtheroids, and the nose swab $N$. catarrhalis. The temperature became normal 24 hours after admission. The baby remained very irritable for 48 hours. Petechiae appeared on both sides of the face and trunk and on the left arm one hour after the initial lumbar puncture and after both subsequent punctures, which were performed with the baby lying on the left side. The maculo-papular rash took 10 days to fade, and the petechiae four more days.

The baby passed two loose stools on October 3, but no pathogens were isolated from a rectal swab.

He was discharged home, well, on October 4 . He was readmitted on October 11 for lumbar puncture and discharged after 24 hours.

Case 10. J.D., aged 4 months, a girl, was admitted on September 22, 1954, from South Ockendon, Essex.

Three days before admission she was very irritable, vomited after all feeds and passed eight green stools. Two days before admission a rash appeared on the face, and diarrhoea continued. On the following day she vomited four times, refused feeds, and was very irritable. 
The rash spread to the body and limbs. On admission her temperature was $100 \cdot 8^{\circ} \mathrm{F}$., pulse 140 , respiration 36 . She was very irritable, and had a discrete, reddish-brown, maculo-papular rash, which faded on pressure, most marked on the face, but also on the trunk, limbs, hands and feet. The fauces and tonsils were red but without exudate. The occipital and cervical lymph nodes were enlarged. Nothing abnormal was found in the cardiovascular, respiratory and central nervous systems, or in the abdomen.

A sample of C.S.F. on September 22 gave 220 cells (all lymphocytes), protein $15 \mathrm{mg}$. per $100 \mathrm{ml}$., sugar, normal reduction, and no growth on culture. On September 30 cells numbered 46 (polymorphs 4, lymphocytes 42), protein $40 \mathrm{mg}$. per $100 \mathrm{ml}$., and on October 8 cells were 10 (lymphocytes) and protein $15 \mathrm{mg}$. per $100 \mathrm{ml}$.

A white blood count gave 18,200 (polymorphs $25^{\circ}$, lymphocytes $75^{\circ}$ ).

Platelets numbered 232,000, and bleeding and clotting times were normal. A throat swab gave a scanty growth of haemolytic streptococci and pneumococci, a nose swab showed Staph. aureus, and no pathogens were isolated from a rectal swab. The Paul Bunnell test was negative.

The temperature became normal in 24 hours: no further vomiting occurred. Numerous petechiae appeared on the face, trunk and limbs after lumbar puncture in the first 24 hours. The rash faded 11 days after admission but the C.S.F. cell count did not reach normal limits until seven days later. The baby was discharged home, well, on October 12.

\section{Clinical Features}

All patients had a similar discrete, reddish-brown, maculo-papular rash on the face, trunk, extensor surfaces of the limbs and the soles of the feet, lasting for three to 14 days. Petechiae were seen in four cases and could be caused to appear by pressure. Nine patients were very irritable and nine were febrile. In eight patients one or more groups of superficial lymph nodes, chiefly occipital and cervical, were enlarged, and in eight the fauces and tonsils were red but no exudate was seen. Five patients vomited and four had diarrhoea, while five were especially difficult with their feeds. No enlargement of the spleen was noted. The child known to be subject to convulsions had numerous myoclonic spasms but the general condition was not otherwise altered.

The babies were ill for one to four days before admission to hospital, and the temperature fell one to five days after admission. Recovery was complete.

\section{Laboratory Investigations}

Lumbar puncture was performed on all cases shortly after admission. Cell counts ranged from 10 to 376 per c.mm. with 25 to $10^{\circ}$ o lymphocytes. Protein, sugar and chlorides were all within normal limits. Bacterial culture was negative. It was repeated on eight cases seven to 14 days later when the cells numbered 2-14 per c.mm.

The white cell counts in the blood ranged from 8,200 to 37,000 per c.mm. with 30 to $75^{\circ}$ o lymphocytes.
Platelet counts, bleeding and clotting times, when carried out, were normal. The Paul Bunnell test, on serum from two cases, was negative.

Throat and nose swabs from all cases failed to reveal any constant pathogenic bacteria, nor were any grown from stools or rectal swabs.

\section{Virus Investigations}

As the illness appeared limited in time, area, the age group involved, and was of uncertain aetiology, virus investigations were undertaken. Samples of faeces and serum, as shown in Table 1, were obtained from nine patients during and after their illness.

Faeces. A $20^{\circ}$ o suspension of each sample in buffered saline solution containing 100 units penicillin and $140 \% \mathrm{~g}$. streptomycin per ml. was centrifuged at 5,000 r.p.m. for a minimum period of one hour at $4=C$. The supernatant fluid was checked for bacterial sterility before being used in virus investigations.

Tissue Culture. Fibroblasts grown from fragments of monkey testis implanted in chicken-plasma-lined tubes and epithelial cells grown from trypsinized suspensions of monkey kidney were used in virus isolation and neutralization tests. Synthetic medium 199 (Morgan, Morton and Parker, 1950) supplemented during the initial period of cell growth with $5^{\circ}$ inactivated horse serum was employed. Tubes were incubated in stationary racks at $37^{2} \mathrm{C}$. For isolation $0.1 \mathrm{ml}$. amounts of faecal suspension were inoculated into five fibroblast and five epithelial cell culture tubes and at least three passages were carried out before any suspension was considered to be negative. Fluids were harvested when cytopathogenic degeneration was evident or after seven and 12 days when absent or equivocal. Successful isolation in epithelial cell cultures with lessening of the toxic effects of the faecal suspensions was also accomplished when medium from a number of culture tubes was exchanged for a period of about two hours with faecal suspension which was then in turn replaced with fresh medium.

Five cytopathogenic agents (Table 1) were isolated from the faecal suspensions. The degenerative changes associated with these were noted in second passage tissue culture tubes four to five days after inoculation. In further passages the changes became more extensive and appeared in a shorter time. The changes initially were more readily apparent in fibroblast culture tubes and in these the five strains produced the same appearance with disruption and rounding of the cells in the immediate neighbourhood of the original tissue fragments. There was a gradual extension to the periphery but complete destruction only occurred in later passages. In epithelial cell cultures the extent of the degenerative change was more variable but with all strains it was limited initially to localized areas in which cells became small, rounded, opaque and finally disappeared, leaving irregular clear spaces surrounded by apparently normal cells. With further passages the destructive effect reached a stage at which it could not be distinguished from the effect produced by standard strains of poliomyelitis virus. 
TABLE 1

SPECIMENS RECEIVED FOR INVESTIGATION AND THE VIRUSES ISOLATED

\begin{tabular}{|c|c|c|c|c|c|c|c|}
\hline \multirow[t]{2}{*}{ Case } & \multirow[t]{2}{*}{ No. } & \multirow[t]{2}{*}{ Sex } & \multirow{2}{*}{$\underset{(\mathrm{mth} .)}{\text { Age }}$} & \multicolumn{2}{|c|}{$\begin{array}{c}\text { Duration of } \\
\text { Illness (days) } \\
\text { when Specimens } \\
\text { Obtained }\end{array}$} & \multicolumn{2}{|c|}{$\begin{array}{l}\text { Virus Isolation } \\
\text { from Faeces }\end{array}$} \\
\hline & & & & Serum & Faeces & $\begin{array}{l}\text { Tissue } \\
\text { Culture }\end{array}$ & $\begin{array}{l}\text { Suckling } \\
\text { Mice }\end{array}$ \\
\hline M.R. & 2 & F & 4 & $\begin{array}{r}6 \\
20\end{array}$ & $\begin{array}{l}3 \\
6\end{array}$ & + & $\overline{-}$ \\
\hline L.H. & 3 & $\mathbf{F}$ & 8 & $\begin{array}{c}-40^{*} \\
23 \\
23\end{array}$ & $\begin{array}{c}-40^{*} \\
4\end{array}$ & $\overline{+}$ & $\pm t$ \\
\hline J. Dr & 4 & $\mathrm{~F}$ & 7 & $\begin{array}{l}1 \\
30\end{array}$ & 2 & + & - \\
\hline S.U. & & F & 9 & $\begin{array}{r}5 \\
95\end{array}$ & - & & \\
\hline $\begin{array}{l}\text { V.B. } \\
\text { P.w. }\end{array}$ & $\begin{array}{l}6 \\
7\end{array}$ & $\stackrel{F}{M}$ & $\begin{array}{r}12 \\
8\end{array}$ & 22 & $\begin{array}{l}2 \\
1\end{array}$ & $\bar{t}$ & $\overline{-}$ \\
\hline M.J. & 8 & $\mathbf{M}$ & 5 & $\begin{array}{r}8 \\
19\end{array}$ & - & & \\
\hline T.B. & 9 & $\mathbf{M}$ & 6 & 21 & 2 & + & - \\
\hline J. Da & 10 & $\mathbf{F}$ & 3 & 250 & - & & i \\
\hline
\end{tabular}

* Previously in hospital with encephalitis following chickenpox.

† Identified serologically as a Coxsackie Group A virus.

No cytopathogenic agents were isolated from the serum obtained from patients during the acute stage of their illness.

Animal Inoculation. Litters of mice less than 1 day old were inoculated subcutaneously with $0.02 \mathrm{ml}$. amounts of each faecal suspension and at least two mouse passages carried out. Suspensions of whole mouse carcase were used for passage. In addition, tissue culture fluids of the various suspensions ranging from first to seventh passage were similarly inoculated. In these tests, as shown in Table 1, a strain of virus later identified serologically as belonging to the Coxsackie A group of viruses was isolated from a sample of faeces which had been obtained from Case 3 during a previous stay in hospital with encephalitis following chickenpox.

Mice, 4-6 weeks old, inoculated intracerebrally with $10^{5}$ tissue culture doses of seventh passage fluid of the agent isolated from Case 4 showed no sign of illness.

Two rhesus monkeys were inoculated intracerebrally $(0.6 \mathrm{ml}$.) and intraperitoneally $(1 \mathrm{ml}$.) with pooled faecal suspensions. Monkey No. 1 received material from Cases 2 and 3 and monkey No. 2 material from Cases $4,6,7,9$. A further $1 \mathrm{ml}$. was given intramuscularly
11 days later and the monkeys were bled a month after the initial injections. Neither monkey had shown any sign of illness or temperature elevation. In tissue culture, cytopathogenic changes followed the inoculation of these two suspension pools but no effect was observed on the chorio-allantoic membranes of 10-day-old fertile hen eggs.

In the preparation of immune serum three guinea-pigs each received two intraperitoneal injections, at an interval of seven days, of third passage tissue culture fluid from Case 4. No reaction or temperature elevation occurred. After a further 11 days each was given intramuscularly $0.2 \mathrm{ml}$. of the same suspension emulsified in an equal volume of adjuvant (Arlacel A: Bayol F). An immune serum was similarly prepared against the agent from Case 9.

Serological Investigations. Neutralization tests were carried out in epithelial cell and to a limited extent in fibroblast cultures. A single dilution of virus suspension (100 tissue culture doses- $\mathrm{TCD}_{50}$ ) was tested against varying dilutions of serum or vice versa. Equal volumes of the serum and virus dilutions were mixed and left at room temperature (about $22^{\circ} \mathrm{C}$.) for one hour. After this time $0.1 \mathrm{ml}$. volumes were inoculated into two or four tubes per dilution. Tubes were examined from the third to the sixth day after inoculation.

Tests with the five newly isolated agents and the postinoculation monkey and guinea-pig sera showed that the agents were closely related immunologically (Tables 2 and 3), but attempts (Table 4) to identify them using (1) specific antiserum against the three types of poliomyelitis virus, individually and combined into one pool, (2) pools of specific antiserum against the $A$ and $B$ groups of Coxsackie virus, (3) herpes simplex antiserum and (4) antiserum against three immunologically distinct strains of enteric cytopathogenic human orphan (ECHO) viruses were all negative. The post-inoculation monkey serum contained no antibody against any type of poliomyelitis virus. Tests with acute and convalescent phase serum from the children and a representative $(\mathrm{C} / 4)$ strain were then carried out. These showed (Table 5) that a considerable rise in antibody level occurred during the course of illness in six patients, and that a high level of antibody was present in the convalescent samples of serum from two patients; in one patient no apparent response occurred. Tests with undiluted serum from the nine patients, either acute or convalescent depending

TABLE 2

TITRATION OF VIRUS SUSPENSIONS AGAINST 1 IN 10 DILUTION OF PRE- AND POST-INOCULATION IMMUNE SERA

\begin{tabular}{|c|c|c|c|c|c|c|c|}
\hline \multirow{2}{*}{ Strain } & \multirow{2}{*}{ No Serum } & \multicolumn{2}{|c|}{ Monkey $(C / 2+C / 3)$ Serum } & \multicolumn{2}{|c|}{ Guinea-pig (C/4) Serum } & \multicolumn{2}{|c|}{ Guinea-pig (C/9) Serum } \\
\hline & & Pre-inoculation & Post-inoculation & Pre-inoculation & Post-inoculation & Pre-inoculation & Post-inoculation \\
\hline $\begin{array}{l}\mathrm{C} / 2^{*} \\
\mathrm{C} / 3 \\
\mathrm{C} / 4 \\
\mathrm{C} / 7 \\
\mathrm{C} / 9\end{array}$ & $\frac{-}{4} \frac{-}{2 \cdot 5}$ & $\begin{array}{l}2 \cdot 5 \dagger \\
4 \cdot 5 \\
4 \\
4 \cdot 5 \\
2 \cdot 5\end{array}$ & $\begin{array}{l}0 \\
0 \cdot 5 \\
0 \cdot 5 \\
0 \\
0\end{array}$ & $\frac{\bar{Z}}{\overline{4}} \overline{2 \cdot 5}$ & $\frac{\overline{0}}{0}$ & $\frac{-}{4} \frac{-}{2 \cdot 5}$ & $\begin{array}{l}\overline{--} \\
1.5 \\
\overline{0.5}\end{array}$ \\
\hline
\end{tabular}


TABLE 3

TITRATION OF A SINGLE DILUTION OF VIRUS SUSPENSION AGAINST DOUBLING DILUTIONS OF IMMUNE SERUM

\begin{tabular}{c|c|c|c|c|c}
\hline \multirow{2}{*}{ Strain } & \multicolumn{2}{|c|}{$\begin{array}{c}\text { Tissue Culture } \\
\text { Doses of Virus } \\
\text { (TCD }\end{array}$} & \multicolumn{2}{|c|}{$\begin{array}{c}\text { Dilutions of } \\
\text { Guinea-pig (C/4) } \\
\text { Immune Serum }\end{array}$} & End-point \\
\cline { 2 - 5 } & Estimated & Final & $1 / 200$ & $1 / 400$ & \\
\hline C/2 & 100 & 320 & $0 / 4^{*}$ & $4 / 4$ & $1 / 280 \dagger$ \\
C/3 & 100 & 1,000 & $0 / 4$ & $4 / 4$ & $1 / 280$ \\
C/4 & 100 & 320 & $0 / 4$ & $4 / 4$ & $1 / 280$ \\
C/7 & 100 & 100 & $0 / 4$ & $3 / 4$ & $1 / 335$ \\
C/9 & 100 & 100 & $1 / 4$ & $4 / 4$ & $1 / 237$ \\
\hline
\end{tabular}

* Number of tubes showing cytopathogenic degeneration over the number inoculated.

+ Estimated by Kaerber's method.

upon availability, against the three types of poliomyelitis virus showed that four already had antibody against Type 1 virus and one of these had antibody against Type 2 virus also.

Similar tests with the C/4 strain and (1) five samples of serum from healthy children less than 2 years old living near the hospital showed that four were negative and one positive with a titre of 1 in 64 . (2) Ten samples of serum from healthy Southend children less than 3 years old were negative. (3) Five samples of convalescent serum from children less than 2 years old and living in separate areas, all with a clinical diagnosis of aseptic meningitis were negative, and (4) two batches of gamma globulin prepared at the Lister Institute of Preventive Medicine showed titres of 1 in 10 and 1 in 40 respectively.

Coxsackie Virus Investigations. Neutralization tests in newborn mice with the Group A strain of virus isolated from the first sample of faeces of Case 3 showed that all three sera from this patient had antibody against this virus but the convalescent samples of serum from Cases 2 , 4,6 and 8 had no antibody. There was insufficient serum from the other patients for these tests.

Complement Fixation Tests. Tests with a number of the convalescent samples of serum and antigens of the influenza A, B, C, the psittacosis-L.G.V. group, mumps, lymphocytic choriomeningitis and the RI-67 strain of APC viruses were negative, and leptospiral agglutination tests were also negative.

Filtration. A tissue culture fluid suspension of the C/4 strain of virus was readily filtered through a gradocol membrane of A.P.D. $94 \mathrm{~m} \mu$. No attempt has yet been made to measure more accurately the size of the virus particles.

\section{Discussion}

The nature of this sudden limited outbreak was puzzling in that it did not correspond with any familiar clinical condition. It was not recognized by general practitioners in the neighbourhood as a common occurrence, and the fact that the illness was confined to very young children with no evidence of older children in the same families being affected,
TABLE 4

NEUTRALIZATION TESTS WITH C/4 AND POLIOMYELITIS VIRUSES AGAINST A NUMBER OF IMMUNOLOGICALLY DISTINCT ANTISERA

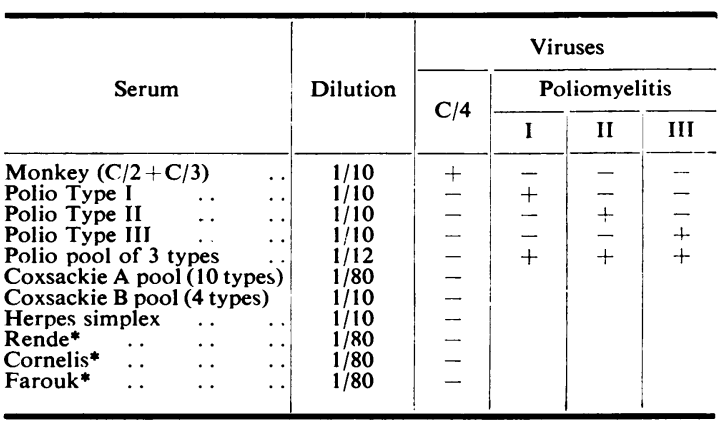

* New Haven echo viruses.

TABLE 5

NEUTRALIZATION TESTS WITH ACUTE AND CONVALESCENT PHASE SERUM OF PATIENTS AGAINST STRAIN C/4 AND THE POLIOMYELITIS VIRUSES

\begin{tabular}{|c|c|c|c|c|c|}
\hline \multirow{2}{*}{$\begin{array}{l}\text { Case } \\
\text { No. }\end{array}$} & \multirow{2}{*}{$\begin{array}{l}\text { Serum } \\
\text { Day of } \\
\text { Illness }\end{array}$} & \multirow{2}{*}{$\begin{array}{c}\text { C/4 Virus } \\
\text { Neutralized } \\
\text { by } \\
\text { Dilution }\end{array}$} & \multicolumn{3}{|c|}{$\begin{array}{l}\text { Undiluted Serum against } \\
\text { Poliomyelitis Viruses }\end{array}$} \\
\hline & & & I & II & III \\
\hline 2 & $\begin{array}{r}6 \\
20\end{array}$ & $\begin{array}{r}64 \\
512\end{array}$ & + & - & - \\
\hline 3 & $\left.\begin{array}{l}-40 \\
-2 \\
23\end{array}\right\}^{*}$ & $\begin{array}{l}<4 \dagger \\
<4 \\
128\end{array}$ & + & $t$ & - \\
\hline 4 & $\begin{array}{l}1 \\
30\end{array}$ & $\begin{array}{r}32 \\
128\end{array}$ & - & - & - \\
\hline 5 & $\begin{array}{r}5 \\
95\end{array}$ & $\begin{array}{r}8 \\
128\end{array}$ & - & - & - \\
\hline $\begin{array}{l}6 \\
7\end{array}$ & $\begin{array}{r}22 \\
1 \\
90\end{array}$ & $\begin{array}{r}512 \\
8 \\
128\end{array}$ & + & - & - \\
\hline 8 & $\begin{array}{r}8 \\
19\end{array}$ & $\begin{array}{r}<4 \\
<4\end{array}$ & - & - & - \\
\hline 9 & 21 & $\begin{array}{r}32 \\
256\end{array}$ & + & - & - \\
\hline 10 & 250 & 256 & - & - & - \\
\hline
\end{tabular}

* Previously in hospital with encephalitis following chickenpox + Reciprocals of the final serum dilutions.

+ Indicates the presence of antibody.

was strongly against a diagnosis of rubella, measles or chickenpox. These diseases were not prevalent in the area at the time. In addition, the rash was too persistent and the patients too irritable for it to be rubella; there was no blotchiness or after staining and no coryza for it to be measles; and no vesicles for it to be chickenpox. Glandular fever was excluded on the grounds of limited age group, constant cerebrospinal fluid changes, the small, rather shotty lymph nodes and the character of the rash. Roseola infantum was excluded because the temperature did not fall as the rash appeared. The total white cell count and degree of lymphocytosis were too low for acute infectious lymphocytosis. Petechiae tended to develop readily in several of the children following lumbar puncture. As the bleeding and clotting times and the platelet counts were 
within normal limits, the petechiae were considered to be traumatic in origin.

Virus studies were undertaken as (1) no pathogenic bacteria seemed to be implicated, (2) the minimal changes in the cerebrospinal fluid suggested a possible virus aetiology including non-paralytic poliomyelitis, and (3) the illness associated with a maculo-papular rash was reminiscent of the epidemic exanthem described by Neva and Enders (1954) and Neva, Feemster and Gorbach (1954). Attempts at isolation were confined to investigation of samples of faeces and serum obtained during the acute phase of illness. It is possible that agents were present in other bodily exudates also, but none was examined. The use of tissue culture in virus studies has become a convenient technique and from this outbreak five cytopathogenic agents were isolated from the six samples of faeces examined. These agents or viruses, as one strain was shown to be filterable through a gradocol membrane $94 \mathrm{~m}: \mu$ A.P.D., did not cause reactions following inoculation into monkeys, mice and guinea-pigs, or on the chorio-allantoic membranes of fertile eggs.

On first isolation these viruses appeared to propagate more readily in monkey testis tissue culture, but after a small number of passages gave rise to extensive cytopathogenic changes in monkey kidney tissue culture also. They were immunologically closely related to each other but distinct from a number of other viruses, including poliomyelitis and Coxsackie viruses. Having been isolated from faeces they come within the enteric group of viruses (Dalldorf, 1952; Ramos-Alvarez and Sabin, 1954). It is noteworthy that, though other tests were negative, increased antibody levels developed in six patients against the newly isolated strains of virus during the course of the illness, and high levels of antibody were found in convalescent samples of serum from two others. The remaining patient did not respond and it is possible that his illness did not come within the same category.

The evidence is suggestive that these viruses played a part in this outbreak. There is also some evidence that their appearance was not a localized incident, as low levels of antibody against them were found when two batches of gamma globulin made from pools of adult serum were examined. Further work on the aetiology of such outbreaks of illness is necessary, but there is no quick road to the solution of the problem in view of the known multiplicity of immunological types among these tissue culture cytopathogenic agents.

\section{Summary}

An outbreak of mild illness in 10 babies admitted to the Shadwell, E.1, branch of the Queen Elizabeth Hospital for Children is described. The principal features were irritability, fever, rash, enlarged superficial lymph nodes, reddening of the fauces and tonsils, vomiting, diarrhoea and changes in the cerebrospinal fluid.

Five strains of virus were isolated in tissue culture. These were found to be immunologically closely related to each other, but distinct from a number of other viruses.

Their role in the aetiology of this illness is discussed.

We are indebted to Dr. I. M. Anderson for permission to publish details of those cases under his care; to Drs. J. A. Dudgeon, G. Dalldorf, J. L. Melnick and J. S. Logan for various sera; and to Drs. B. E. Andrews and L. A. Hatch for the results of complement fixation tests with other viruses.

Dalldorf, G. (1952). J. Mt Sinai Hosp., 19, 396.

Morgan, J. F.. Morton, H. J. and Parker, R. C. (1950). Proc. Soc. exp. Biol. (N.Y.). 73, 1 .

Neva, F. A. and Enders, J. F. (1954). J. Immunol., 72, 315.

Feemster, R. F. and Gorbach, I. J. (1954). J. Amer. med. Ass., 155,544 .

Ramos-Alvarez. M. and Sabin, A. B. (1954). Proc. Soc. exp. Biol. (.N.Y.), 87, 655 . 